Volume 02 Nomor 02, Desember 2020 Page 1-8

Incrementapedia: Jurnal Pendidikan Anak Usia Dini

Program Studi PG-PAUD Fakultas Pedagogik dan Psikologi

Universitas PGRI Adi Buana Surabaya

http://jurnal.unipasby.ac.id/index.php/incrementapedia

e-ISSN: 2686-3146

\title{
KESIAPAN DAN KETERLIBATAN PENDIDIK PAUD DI JAWA TIMUR PADA MASA PANDEMIK COVID-19 MELALUI PENGUASAAN TIK
}

\author{
Kristin Anggraini ${ }^{1}$, Danang Prasetyo ${ }^{2}$ \\ ${ }^{1}$ PG-PAUD FKIP Universitas Katolik Widya Mandala Surabaya \\ ${ }^{2}$ Institut Agama Islam Negeri Madura \\ email: krisanggi@gmail.com
}

\begin{abstract}
This research was driven by a change in the implementation of learning in PAUD during the Covid-19 pandemic virus, which was originally conducted face-to-face and turned into virtual. Based on this, the researcher wants to know the readiness, willingness and involvement of PAUD educators in implementing virtual learning. This research is a qualitative research with literature-based data sources collected from several articles contained in various international journals and surveys that have been conducted to about two hundred and fifty-six teachers in East Java who confirmed that as many as $10.5 \%$ stated strongly agree, as many as 50.4\% agreed while 39.1\% stated that they did not agree / were not willing to support efforts to implement virtual learning for early childhood. The results of this study are expected to be a recommendation for policy makers to carry out virtual learning in early childhood classes in order to break the chain of the spread of the Covid-19 virus in Indonesia.
\end{abstract}

Keywords: virtual learning, PAUD teacher willingness

\section{PENDAHULUAN}

Mulai akhir tahun 2019 hingga pertengahan tahun 2020, dunia sedang dilanda oleh penyebaran virus yang bernama coronavirus disease 2019 (COVID-19), dinamakan demikian karena pinggiran luar protein dari jenis virus ini menyerupai mahkota ('corona' dalam bahasa Latin). Virus jenis ini merupakan keluarga virus RNA (Burrell et al., 2017). Keadaan ini pertama kali dilaporkan pada Desember 2019, setelah melakukan penyelidikan maka Organisasi Kesehatan Dunia (WHO) mengumumkannya sebagai ancaman global yang menjadi perhatian internasional pada tanggal 31 Januari 2020 serta diumumkan sebagai pandemi pada tanggal 11 Maret 2020 (Shan L. Pana et al,
2020). Bahkan menurut Worldometer (worldometers.info) secara real time menunjukkan bahwa jumlah kasus Covid-19 per tanggal $27 \mathrm{Mei}$ 2020 di dunia sebanyak 5.689.212 orang dan telah menginfeksi sedikitnya 215 negara.

Covid-19 umumnya patogen terhadap mamalia dan burung serta dapat menyebabkan infeksi saluran pernapasan atas yang umumnya ringan pada manusia. Virus ini dapat pula ditularkan pada populasi manusia yang lebih besar dan dapat menyebabkan penyakit pernafasan yang parah seperti Sindrom Pernafasan Akut Parah (SARS) dan Sindrom Pernafasan yang terjadi di Timur-Tengah (MERS) yang terjadi pada tahun 2003 dan 2012. Oleh karena itu WHO menegaskan untuk membatasi penularan, memberikan perawatan dini, 
mengomunikasikan informasi utama dan meminimalkan dampak sosial dan ekonomi. (WHO, 2020). Pemerintahpun akhirnya menerapkan peraturan bagi seluruh lapisan masyarakat untuk menjaga jarak (physical distancing) dalam upaya memutus rantai penyebaran virus Covid-19 ini.

Sejak diberlakukannya peraturan pemerintah mengenai physical distancing, maka semua aktivitas masyarakat mulai dibatasi tak terkecuali pada sektor pendidikan. Untuk mendukung upaya Pemerintah dalam memutus rantai penyebaran Covid-19 maka sekolah-sekolah diliburkan, mulai dari jenjang PAUD hingga Perguruan Tinggi. Aktivitas pembelajaran pun berubah, yang awalnya pembelajaran dilakukan dengan tatap muka maka semenjak adanya pemberlakuan physical distancing pembelajaran dilakukan secara virtual baik dalam jaringan (daring) maupun di luar jaringan (luring). Dalam hal ini, maka para pendidik pun diharapkan dapat beradaptasi dengan cepat untuk mengubah model pembelajaran tatap muka menjadi virtual. Tak terkecuali para pendidik PAUD, mereka juga wajib beradaptasi dan mampu menghadirkan pembelajaran daring di dalam kelas.

Menghadirkan kelas virtual dalam pembelajaran PAUD merupakan tantangan tersendiri bagi para pendidik, mengingat tujuan dari pembelajaran di PAUD adalah mengembangkan seluruh aspek perkembangan anak. Dengan kata lain bahwa pembelajaran di PAUD sangat menekankan pada kehadiran secara fisik baik pendidik maupun peserta didik, namun dengan adanya pandemik ini semuanya seolah dipaksakan untuk berubah.

Adapun penelitian terhadap guru yang ada kaitannya dengan penggunaan ICT dalam pembelajaran di kelas anak usia dini telah dilakukan diantaranya oleh J. Enrique Hinostroza*, Christian Labbé, Carolina Matamala dengan judul The use of computers in preschools in Chile: Lessons for practitioners and policy designers, Daciana Lupua, Andreea Ramona LaurenGiiub berjudul Using New Communication and Information Technologies in Preschool Education. Dari kedua penelitian yang telah dilakukan tersebut, menunjukkan pentingnya penggunaan ICT bagi guru dan peserta didik.

Sementara itu, penelitian kesiapan dan keterlibatan pendidik PAUD di Jawa Timur pada masa pandemik COVID-19 melalui penguasaan TIK belum pernah dilakukan. Sehingga, hasil penelitian ini dapat dijadikan rekomendasi bagi para pemangku kebijakan untuk melaksanakan pembelajaran secara virtual di kelas-kelas PAUD dalam rangka memutus rantai penyebaran virus Covid-19 di Indonesia.

Berdasarkan latar belakang di atas maka fokus pemasalahan pada penelitian ini adalah bagaimana kesiapan dan keterlibatan para pendidik PAUD di Jawa Timur pada masa pandemik COVID-19 melalui penguasaan TIK?

\section{METODE PENELITIAN}

Penelitian ini merupakan penelitian deskriptif kualitatif dengan teknik pengumpulan data melalui kajian literatur dan survei. Survei dilakukan pada 26 Mei sampai dengan 21 Juni 2020 kepada dua ratus lima puluh enam responden yang merupakan para guru Pendidikan Anak Usia Dini (PAUD) di seluruh Jawa Timur. Pemilihan responden ini dengan pertimbangan bahwa dua ratus lima puluh enam guru yang bersangkutan adalah guru anak usia dini 
yang tengah mengalami perubahan dalam pembelajaran sehari-hari di kelas karena terdampak Covid-19. Hal ini tentu sesuai dengan kredibilitas dan kapasitas mereka dalam menganalisis. Survei dilakukan melalui pengisian pertanyaan-pertanyaan yang dibagikan kepada seluruh responden dalam bentuk google form. Komponen yang terdapat dalam kuesioner terdiri atas beberapa pertanyaan terkait penguasaan TIK oleh para guru PAUD yang meliputi lama mengajar, pengetahuan guru tentang perangkat komputer sekaligus penggunaanya, ketersediaan perangkat dan jaringan internet di sekitar guru, serta kesiapan sekaligus keterlibatan guru dalam pembelajaran secara virtual di kelas PAUD. Selanjutnya seluruh data yang terkumpul baik dari kajian literatur maupun hasil survei dianalisis untuk dideskripsikan.

\section{HASIL PENELITIAN}

Pada masa pandemik Covid-19 ini semua sektor di dunia ini merasakan dampaknya, begitu pula dengan dunia pendidikan. Aktivitas pembelajaran pun berubah, yang awalnya pembelajaran dilakukan dengan tatap muka maka semenjak adanya pemberlakuan physical distancing guna menekan penyebaran Covid-19 maka pembelajaran dilakukan secara virtual baik dalam jaringan (daring) maupun di luar jaringan (luring). Dengan demikian untuk melihat kesiapan dari para pendidik dalam menghadapi perubahan aktivitas pembelajaran tersebut, maka peneliti pun melakukan penelitian terhadap sekitar dua ratus lima puluh enam orang guru yang memiliki masa kerja bervariasi seperti yang tertera pada tabel 1 berikut.
Tabel 1. Pengalaman Mengajar Guru PAUD Jawa Timur

\begin{tabular}{|c|c|c|c|}
\hline & 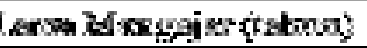 & tornizite & 5 \\
\hline \multirow{9}{*}{$\boldsymbol{r}$} & $i-5$ & 彭 & 全泫的 \\
\hline & 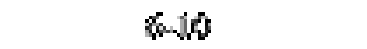 & 18 & $x 7 \%$ \\
\hline & $x:-15$ & 2 & 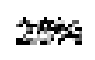 \\
\hline & $\alpha-20$ & $3 i$ & $10 \% 5$ \\
\hline & $2-25$ & لذ & 466 \\
\hline & $x-3$ & $z$ & 135 \\
\hline & F-15 & 4 & 20 \\
\hline & 起- & 4 & $2 x$ \\
\hline & 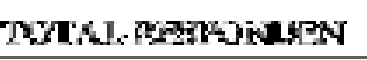 & $x y$ & Lixp's \\
\hline
\end{tabular}

Tabel di atas menunjukkan bahwa responden yang berasal dari guru PAUD telah memiliki pengalaman dari lama mengajar yang cukup. $73 \%$ guru PAUD di Jawa Timur memiliki pengalaman mengajar di atas 5 (lima tahun). Dengan demikian data ini dapat digunakan sebagai acuan tentang kesiapan guru dalam menghadapi perubahan pembelajaran yang semula dilakukan dengan tatap muka menjadi virtual selama masa pandemik.

Dalam melakukan pembelajaran virtual ada beberapa hal yang harus dipahami bahkan disiapkan oleh para pendidik, diantaranya pengetahuan pendidik/guru tentang perangkat komputer dan cara menggunakannya. Di bawah ini adalah diagram yang menunjukkan bahwa ada sebanyak $60,9 \%$ yang menyatakan sangat setuju telah mengetahui tentang fungsi dasar dari perangkat komputer/laptop, dan 37,9\% menyatakan setuju telah mengetahui fungsi dasar dari perangkat komputer/laptop, sedangkan sebanyak 1,2\% menyatakan tidak setuju/tidak mengetahui fungsi dasar dari perangkat komputer/laptop. Hal ini dapat dilihat pada grafik berikut ini. 

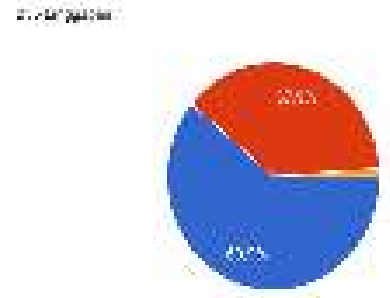

Grafik 1. Tingkat Pengetahuan Guru PAUD tentang fungsi dasar dari perangkat komputer/laptop

Dalam hal mengetahui cara mengoperasikan komputer/laptop misalnya menympan dan membuka dokumen, menggunakan perangkat lunak (MS. Word, MS. Excel, MS. Power Point), para responden menyatakan bahwa sebanyak 54,7\% setuju telah mengetahui cara mengoperasikan komputer/laptop, dan 43,8\% menyakatan setuju telah mengetahui cara mengoperasikan komputer/laptop, sedangkan sebanyak 1,6\% tidak setuju/tidak mengetahui cara mengoperasikan komputer/laptop. Hal tersebut ditunjukkan pada grafik 2 di bawah ini.
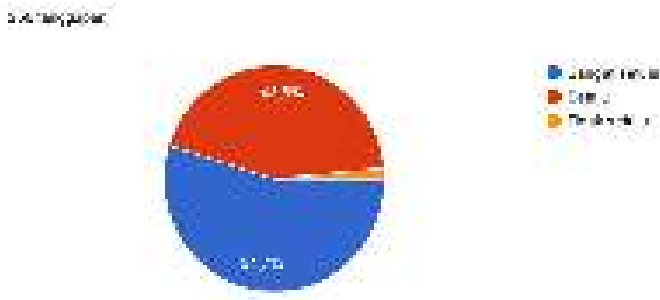

Grafik 2. Tingkat Pengetahuan Guru PAUD mengenai cara mengoperasikan komputer/laptop

Selain penguasaan IT atau kemampuan guru dalam mengoperasikan komputer/laptop, hal penunjang lainnya adalah ketersediaan perangkat komputer/laptop pribadi dengan koneksi internet di sekitar tempat tinggal guru ditunjukkan pada grafik 3.
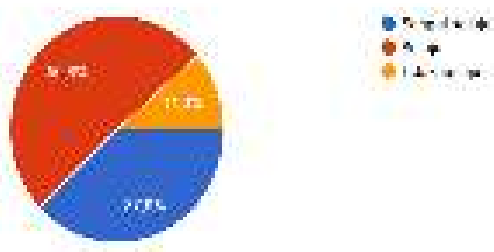

Grafik 3. Ketersediaan perangkat komputer/laptop pribadi dengan koneksi internet di sekitar tempat tinggal guru

Grafik di atas menunjukkan bahwa sebanyak $37,9 \%$ responden sangat setuju jika memiliki ketersediaan perangkat komputer/laptop pribadi dengan koneksi internet di sekitar tempat tinggal guru, sebanyak 50,8\% menyatakan setuju adanya ketersediaan perangkat komputer/laptop pribadi dengan koneksi internet di sekitar tempat tinggal guru, sedangkan sebanyak 11,3\% menyatakan tidak setuju kalau harus menyediakan perangkat komputer/laptop dengan koneksi internet di sekitar tempat tinggal guru secara pribadi.

Ketersediaan jaringan internet juga memegang peranan dalam pelaksanaan pembelajaran virtual, karena apabila suatu daerah belum terjangkau jaringan internet maka daerah tersebut dapat dinyatakan mustahil dapat melakukan pembelajaran secara virtual tersebut. Dari grafik 4 dapat diketahui adanya pernyataan mengenai ketersediaan jaringan internet di sekitar tempat tinggal guru yaitu sebnayak $28,5 \%$ menyatakan sangat setuju bahwa di daerahnya ada jaringan internet, sebanyak 59,4\% menyatakan setuju bahwa terdapat jaringan internet di sekitar tempat tinggalnya sedangkan sebanyak $12,1 \%$ menyatakan tidak setuju bahwa jaringan internet berada di sekitar tempat tinggal guru. 


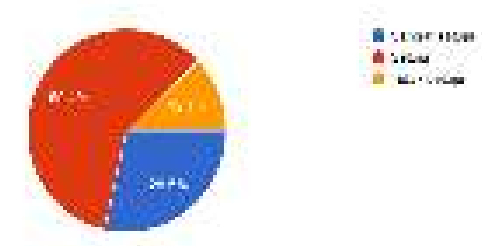

Grafik 4. Ketersediaan jaringan internet di sekitar tempat tinggal guru

Para guru PAUD ternyata telah memiliki kesiapan untuk melakukan pembelajaran virtual jauh sebelum adanya pandemik Covid-19. Hal ini ditunjukkan pada grafik 5 berikut. Responden menyatakan bahwa sebanyak $14,1 \%$ sangat setuju telah memiliki kesiapan untuk melakukan pembelajaran virtual jauh sebelum adanya pandemik Covid-19, sebanyak 64,1\% setuju bahwa memiliki kesiapan untuk melakukan pembelajaran virtual jauh sebelum adanya pandemik Covid-19 sedangkan sebanyak $21,9 \%$ menyatakan tidak setuju/tidak memiliki kesiapan untuk melakukan pembelajaran virtual jauh sebelum adanya pandemik Covid-19.
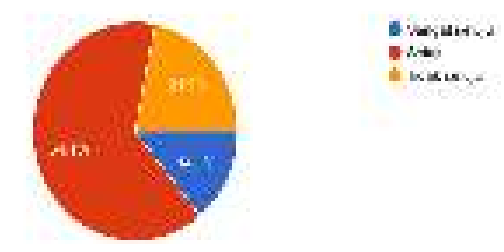

Grafik 5. Kesiapan Guru PAUD untuk melakukan pembelajaran virtual jauh sebelum adanya pandemik Covid-19

Pada beberapa bulan ini para guru juga telah mulai menerapkan pembelajaran virtual di kelaskelas PAUD, sehingga mereka dapat merasakan dan membandingkan antara pelaksanaan pembelajaran tatap muka dan pembelajaran virtual. Berdasarkan data yang telah diambil dapat diketahui bahwa ada sebanyak $8,6 \%$ menyatakan sangat setuju bahwa melalui pembelajaran virtual merasa semakin dipermudah dalam melakukan kegiatan pembelajaran bagi setiap peserta didik, sebanyak $50 \%$ merasa setuju sedangkan sebanyak 41,4\% menyatakan tidak setuju bahwa melalui pembelajaran virtual kegiatan pembelajaran bagi setiap peserta didik semakin dipermudah. Hal ini ditunjukkan pada grafik 6 di bawah ini.
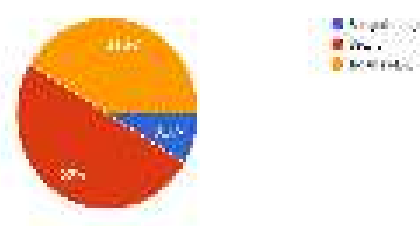

Grafik 6. Persepsi Guru PAUD

tentang Pembelajaran virtual mempermudah kegiatan pembelajaran bagi peserta didik

Pada penelitian ini para guru PAUD juga menyatakan kesediaannya dalam mendukung upaya pemberlakuan pembelajaran virtual bagi anak usia dini, yaitu sebanyak 10,5\% menyayakan sangat setuju, sebanyak 50,4\% setuju sedangkan sebanyak $39,1 \%$ menyatakan tidak setuju/tidak bersedia dalam mendukung upaya pemberlakuan pembelajaran virtual bagi anak usia dini. Hal ini ditunjukkan pada grafik 7 di bawah ini.
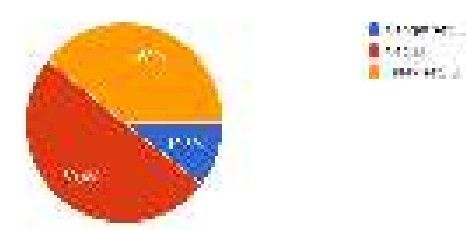

Grafik 7. Kesediaan guru dalam mendukung upaya pemberlakuan pembelajaran virtual bagi anak usia dini.

\section{PEMBAHASAN}

Walaupun infeksi yang ditimbulkan oleh Covid-19 pada anak tergolong ringan, tetapi anak usia dini tergolong kelompok yang rentan terpapar Covid-19. Sisi berisiko anak usia dini lainnya 
adalah kemungkinan ia akan menjadi carrier atau pembawa virus yang menyebarkan kepada orang lain, sehingga pembelajaran di PAUD pun harus dilakukan secara virtual pula. Pembelajaran secara virtual harus didukung dengan perangkat dan jaringan yang memadai di sekitar tempat tinggal guru, selain itu kemampuan guru dalam mengoperasikan perangkat komputer/laptop juga memegang peranan penting. Hasil penelitian ini menunjukkan bahwa para guru telah memiliki kesiapan dalam hal penguasaan IT dan juga telah didukung dengan adanya ketersediaan perangkat komputer/laptop pribadi serta jaringan internet yang memadai di sekitar tempat tinggal guru. Dengan demikian menumbuhkan anggapan dari para guru bahwa pembelajaran virtual mempermudah kegiatan pembelajaran bagi peserta didik. Hasil survei persepsi dari para guru PAUD yang berjumlah dua ratus lima puluh enam responden menyatakan sebagian besar mendukung upaya pemberlakuan pembelajaran virtual bagi anak usia dini. Dari itu, hasil penelitian ini dapat dijadikan rekomendasi bagi para pemangku kebijakan untuk melaksanakan pembelajaran secara virtual di kelaskelas PAUD dalam rangka memutus rantai penyebaran virus Covid-19 di Indonesia.

Hasil penelitian ini memunjukkan bahwa pengetahuan guru mengenai perangkat komputer/laptop serta kemampuan dalam mengoperasikannya sudah bagus dan hal ini sangat mempengaruhi pelaksanaan pembelajaran yang dilakukan secara online/daring. Selain itu ketersediaan perangkat serta jaringan internet di sekitar tempat tinggal guru pun sudah cukup memadai. Pengalaman mengajara para pendidik PAUD di Jawa Timur rata-rata sudah sangat memadai. 55\% guru PAUD memiliki pengalaman mengajar antara 6 sampai dengan 15 tahun, 14\% memiliki pengalaman mengajar antara 16 sampai 25 tahun, dan $4 \%$ berpengalaman lebih dari 25 tahun. Dari data tersebut 94\% $(27 \%+27 \%$ $28 \%+10 \%+4 \%$ ) adalah kelompok guru yang tergolong usia produktif dan mampu beradaptasi dengan perkembangan IPTEK, dalam hal ini teknologi informasi dan komunikasi (TIK). Hal ini tentunya sangat memengaruhi kesiapan dari para guru (pendidik) dalam mendukung pelaksanaan pembelajaran online/daring yang dilakukan sehingga berdampak positif dalam upaya menghambat laju penularan virus Covid-19, terlebih bagi anak usia dini. Hal ini ditunjang oleh 78,2\% (lihat grafik 5) pendidik PAUD di Jawa Timur siap mendukung pembelajaran virtual (daring) untuk anak usia dini melalui penguasaan teknologi informasi dan komunikasi. Lebih-lebih saat ini (98,5\%) pendidik PAUD di Jawa Timur sudah melek IT. (lihat grafik 1).

\section{SIMPULAN DAN SARAN}

\subsection{Simpulan}

Berdasarkan hasil survey yang peneliti lakukan dapat disimpulkan bahwa para pendidik PAUD di Jawa Timur pada dasarnya telah memiliki kesiapan dalam hal penguasaan IT dan juga telah didukung dengan adanya ketersediaan perangkat komputer/laptop pribadi serta jaringan internet yang memadai di sekitar tempat tinggal guru, dan sebagian besar pendidik mendukung upaya pemberlakuan pembelajaran virtual bagi anak usia dini pada masa pandemik covid-19 ini. 


\subsection{Saran}

Berdasarkan hasil penelitian yang telah dilakukan mengenai kesiapan dan keterlibatan para pendidik PAUD di Jawa Timur pada masa pandemik COVID-19 melalui penguasaan TIK, maka peneliti mengemukakan saran sebagai berikut:

a. Para pendidik memerlukan kemampuan dalam hal mengoperasikan komputer/laptop yang sangat dibutuhkan dalam melaksanakan pembelajaran secara online/daring. Terkait hal tersebut di atas, maka perlu adanya dukungan dari Dinas Pendidikan Kabupaten/Kota setempat dalam memberikan fasilitas pelatihan IT bagi para guru, organisasi guru seperti IGTKI/HIMPAUDI pun dapat memberikan dukungan serupa serta motivasi dari para pendidik secara pribadi dalam rangka meningkatkan kompetensi juga sangat diperlukan.

b. Para pendidik juga memerlukan ketersediaan berbagai perangkat komputer/laptop beserta jaringan internet di sekitar tempat tinggal pendidik untuk mempermudah penyampaian materi melalui pembelajaran online/daring. Ketersediaan perangkat ini sebaiknya dilakukan oleh para guru secara mandiri, dan dapat juga difasilitasi oleh Yayasan yang menaungi lembaga PAUD dimana pendidik tersebut mengajar.

c. Kesiapan dan keterlibatan pendidik dalam hal fisik dan psikis juga sangat mempengaruhi pelaksanaan pembelajaran berbasis IT tersebut. Oleh karenanya, perlu dukungan dari berbagai pihak dalam mewujudkan kesiapan dan keterlibatan para pendidik dalam pelaksanaan pembelajaran berbasis IT diantaranya dukungan dari pihak sekolah dan Yayasan yang selalu memberikan dukungan baik moril maupun materiil kepada para pendidik sebagai bentuk apresiasi, selain itu juga dukungan dari para orang tua/wali murid pun diperlukan. Dukungan dari para orang tua/wali murid sangat dibutuhkan karena selama pelaksanaan pembelajaran virtual para peserta didik belajar dari rumah, sehingga orang tua/wali murid merupakan rekan sekerja para pendidik.

Adanya berbagai kesiapan dan keterlibatan pendidik dalam hal sarana prasarana juga kesiapan baik fisik dan mental akan mempermudah pelaksanaan pembelajaran secara online/daring yang dilakukan selama masa pandemik Covid-19 ini.

\section{REFERENSI}

Burrell, C.J., Howard, C.R., Murphy, F.A., (2017). Chapter 31 - Coronaviruses, in: Burrell, C.J., Howard, C.R., Murphy, F.A. (Eds.), Fenner and White's Medical Virology (Fifth Edition). Academic Press, London, pp. $437-$ 446.

Daciana Lupua, Andreea Ramona LaurenǴiub. (2015). Using New Comunication and Information Technologies in Preschool Education. Procedia - Social and Behavioral Sciences 187 (2015) 206-210

J. Enrique Hinostroza*, Christian Labbé, Carolina Matamala. (2013). The use of computer in preschool in Chile: Lessons for practitioners and policy designers. Computers \& Education 68 (2013) 96-104

Shan L. Pana, Miao Cuib, ${ }^{*}$, Jinfang Qianc. (2020). Information resource orchestration during the COVID-19 pandemic: A study of community lockdowns in China. International Journal of Information Management 54 (2020) 102143 
WHO, (2020). Rolling updates on coronavirus disease (COVID-19). URL

https://www.who.int/emergencies/diseases/n ovel-coronavirus-2019/events-astheyhappen (accessed 3.31.20).

Worldometers.info, diakses pada $27 \mathrm{Mei}$ 2020 